Przykarpacki Narodowy Uniwersytet imienia W. Stefanyka Uniwersytet Narodowy «Akademia Ostrogska»

\author{
Olga Łazarowycz \\ Halina Krajczyńska
}

\title{
Uczymy się pisać poprawnie
}


УДК 811.162.1'35

ББК 81

л17

Рекомендовано до друку Вченою радою факультету філології ДВНЗ «Прикарпатський національний університет імені Василя Стефаника» (протокол № 8 від 23 квітня 2020 року)

\section{Рецензенти:}

А. М. Архангельська, доктор філологічних наук, професор кафедри славістики університету ім. Ф. Палацького (Оломоуц, Чехія) ;

О. М. Пелехата, доцент кафедри слов'янських мов Факультету філології ДВНЗ «Прикарпатський національний університет імені Василя Стефаника».

\section{Лазарович О. М., Крайчинська Г. В.}

Uczymy się pisać poprawnie: навчально-методичний посібник з польської орфографії. Острог: Видавництво Національного університету «Острозька академія», 2021. 118 c.

\section{DOI $10.25264 / 23.04 .2020$}

Навчально-методичний посібник з польської орфографіï «Uczymy się pisać poprawnie» призначений для студентів філологічних та нефілологічних спеціальностей, а також всім, хто прагне вивчити орфографію польської мови.

\section{УДК 811.162.1'35}

$$
\text { ББК } 81
$$

(C) Лазарович О. М., Крайчинська Г. В., 2021

\section{Spis treści}

Wstęp

Przyczyny powstawania i rodzaje błędów ortograficznych .............7

Podstawy ortografii polskiej ….................................................................... 8

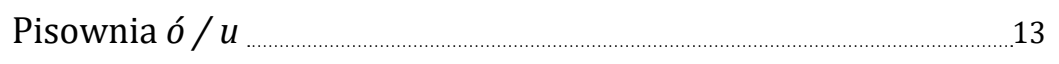

Pisownia $c h / h \quad 24$

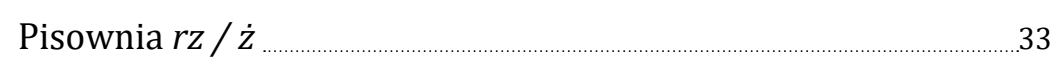

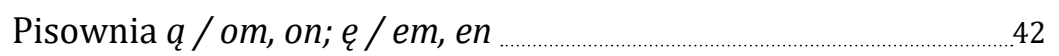

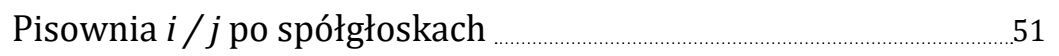

Pisownia wyrazów z sylabami kie, gie, ke, ge, ke, ge ............................57

Pisownia łączna i rozdzielna $\quad 59$

Pisownia cząstek -by, -bym, -byś, -byśmy, -byście …………………….....5

Przeczenie nie z różnymi częściami mowy ……………………....................63

Przyimki złożone, wyrażenia przyimkowe _............................................ 71

Pisownia przedrostków bez-, roz-, $z^{-},\left(s^{-}, s^{-}\right)$, wez-, wz-, (wes-, ws-)

Pisownia końcowych cząstek wyrazów …..................................................... 81

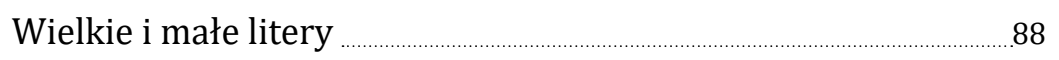

Skróty. Kropka po cyfrze. Łącznik. Dzielenie wyrazów

w piśmie

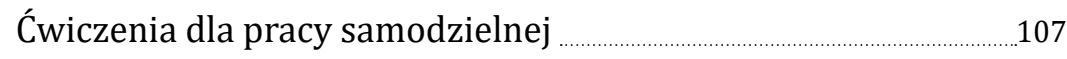

Bibliografia 
Метою видання даного посібника є зняття труднощів при навчанні польської орфографії. У посібнику систематизовано основні правила польської орфографії та тексти і вправи дидактичного характеру, які підібрані 3 урахуванням функціонального підходу до вивчення польської мови й спрямовані на закріплення вивченого матеріалу та самостійної перевірки набутих навичок. Вправи допоможуть проаналізувати помилки, перевірити й запам'ятати правила правопису, а також сприятимуть формуванню орфографічної свідомості. Порядок розміщення вправ дозволяє випробувати власні сили i, спираючись на засвоєний матеріал, безпомилково писати слова та тексти.

Опанування польською орфографією вимагає терпеливості і систематичності, тому бажаємо не втрачати надії, якщо перші спроби написання вас не задовільнять. Навчитися правильно писати можна лише завдяки наполегливій праці.

\section{Wstęp}

Można by ich (ortografji, pisowni, interpunkcji) barwę emocjonalną zestawić z dokuczliwością ubierania buta. A jednak w odczuciu społecznym błąd ortograficzny traktowany jest jako oznaka braku elementarnej kultury, gorzej niż np. pomyłka w mnożeniu czy pomieszanie ważnych nazwisk lub dat historycznych.

Jan Tokarski.

Ortografia (gr. orthós - prawidłowy, grafo - piszę) ustala w sposób normatywny zasady poprawnej pisowni oraz poprawną pisownię poszczególnych wyrazów, wyrażeń i zwrotów. Zbiór obowiązujących obecnie zasad polskiej ortografii, zatwierdzonych przez Komitet Językoznawstwa PAN i zaleconych przez Ministerstwo Oświaty do użytku w szkołach, zawierają słowniki ortograficzne.

Pisownia to $\mathrm{w}$ znacznej mierze sprawa tradycji. Piszemy jakiś wyraz w określony sposób, dlatego że tak się go pisało i pisze. W zasadniczych zrębach zasady pisowni polskiej zostały ustalone przez autorytetne ciała kolegialne (Komitet Ortograficzny Polskiej Akademii Umiejętności w roku 1936 i Komitet Językoznawstwa Polskiej Akademii Nauk w roku 1956). Najważniejsze rozbieżności między pisownią a wymową, te, które sprawiają zasadnicze trudności, zwłaszcza we wczesnych fazach nauki języka polskiego: pisownia ó i u na miejscu tej samej głoski [u], pisownia rz i ż (albo sz) na miejscu tych samych głosek oraz pisownia h i ch - mają znacznie dłuższą historię.

Współczesna ortografia polskajest odziedziczona zwczesniejszych okresów rozwojowych polszczyzny. Jeśli chodzi o podane wyżej przykłady dziszejszych trudności ortograficznych, to powstały one 
skutkiem zmian w języku polskim na przestrzeni wieków. W XVI wieku litery u i ó pisano w miejscu różnych głosek. Podobnie różnym głoskom odpowiadały ż i rz. Pisownia jest bowiem uwarunkowana wymową: pisząc po polsku, w zasadzie oddajemy na piśmie brzmienie wyrazów polskich. Jednak nie ma tu odpowiedniości dokładnej. Rozbieżności między mową a pismem wynikają w dużej mierze ze zmian historycznych: dawniej, gdy kształtowała się polska ortogfafia, napisy znacznie dokładniej oddawały wymowę niż obecnie.

Niektóre dawne uzasadnienia fonetyczne pisowni polskiej przekształciły się $\mathrm{w}$ morfologiczne: uzasadniamy często pisownię słowa nie jego wymowa, ale budową i powiązaniami $\mathrm{z}$ innymi słowami (innymi formami tego samego wyrazu odmiennego albo wyrazami pokrewnymi). Mówimy wtedy o wymianach głosek. Słowo stóg wymawiamy [stuk] - tak samo, jak słowo stuk, ale piszemy je przez óg, bo w innych formach tego rzeczownika występują w wymowie głoski $[o]$, i $[g]$ (bo: stogu). Z kolei pisownię wyrazu stożek przez ż mozemy uzasadnić przez wskazanie jego pokrewieństwa z wyrazem stóg, w którym występuje brzmiące i pisane g: głoska [ż] wymienia się $\mathrm{z}[g]$.

Zastanawiając się nad problemami ortograficznymi i uzasadniając pisownię konkretnych wyrazów, często odwołujemy się do sposobu ich wymawiania. Abyś dobrze rozumiał uzasadnienia pisowni wielu wyrazów, powinieneś zdawać sobie sprawę z tego, że inne są podstawowe jednostki tekstu pisanego - litery, a inne, mowy brzmiącej, - głoski. W zasadach pisowni i zestawieniu trudniejszych zakończeń wyrazów odwołujemy się niekiedy do postaci brzmiącej wyrazu, nie zaś do jego zapisu oftograficznego: zapis wymowy podajemy wtedy w nawiasie kwadratowym.

\section{Przyczyny powstawania i rodzaje błędów ortograficznych}

Poprawność ortograficzna polega na zgodności zapisów zaktualnie obowiązującymi zasadami pisowni. Wszelkie odstępstwa od tych zasad są uważane za błędy ortograficzne. Przyczyną ich powstawania jest najczęściej nieznajomość przepisów ortograficznych, lub osłabienie pamięci, myślenia, uwagi, spostrzegania, woli.

Niewiedza lub niewłaściwe rozumienie zasad poprawnej pisowni prowadzi do przekonania o słuszności błędnej formy zapisu. Jest to podstawowy rodzaj błędów, tzw. znajdowanie się $w$ błędzie ${ }^{1}$, wynikające z nieświadomości istnienia problemu ortograficznego.

Drugi typ błędów to błąd z powodu wahania, czyli spowodowany niepewnością, jak zastosować znaną regułę ortograficzną. Wynika on najczęściej z osłabienia pamięci i uwagi.

Trzeci rodzaj błedów ortograficznych to bład z braku zastanowienia się lub z powodu fałszywej reakcji. Może być spowodowany niedomaganiem pewnych funkcji psychicznych (spostrzegania, myślenia, pamięci, uwagi, woli) albo wynika z niewiary piszącego $\mathrm{w}$ swoje siły lub z braku ambicji opanowania ortografii.

Niepoprawność zapisu bywa niekiedy tylko omyłką, która na ogół wynika z pośpiechu, braku zainteresowania pracą, zaabsorbowania innymi sprawami, czasem z wyczerpania, choroby, zmęczenia.

Najczęściej popełnianymi omyłkami są:

- opuszczanie liter w wyrazach;

- zamiana jednych liter na drugie;

- niedopisywanie znaków odróżniających litery (kropki nad $i$; przecinka jako graficznego znaku miękkości, np. ć, ź, ś; zakończeń przy literach oznaczających samogłoski nosowe $q, e$ ).

\footnotetext{
${ }^{1}$ Wojcik J. Ortografii i interpunkcji nauczę się sam. - Warszawa, 1989.
} 
Навчально-дидактичне видання

Автори-укладачі

Ольга Миколаӥвна ЛАЗАРОВИЧ,

Галина Вацлавівна КРАЙЧИНСЬКА

\section{UCZYMY SIĘ PISAĆ POPRAWNIE}

\section{Навчально-методичний посібник з польської орфографії}

Комп'ютерна верстка Наталії Крушинської

Формат 42х30/4. Ум. друк. арк. 6,86. Зам. № 8-21.

Наклад 100 пр. Папір офсетний. Друк цифровий. Гарнітура «Cambria».

Оригінал-макет виготовлено у видавництві

Національного університету «Острозька академія»,

Україна, 35800, Рівненська обл., м. Острог, вул. Семінарська, 2.

Свідоцтво суб’єкта видавничої справи РВ № 1 від 8 серпня 2000 року.

Виготовлено: ФОП Свинарчук М. В., тел.: +38(068) 6835 800, e-mail: 35800@ukr.net 